\title{
COURAGE AND KNOWLEDGE AT PROTAGORAS 349E1-351B2
}

\author{
David Wolfsdorf, Temple University \\ SAGP at Philologists, Montreal January 2006
}

\section{INTRODUCTION}

At Protagoras 349E1-350C5 Socrates argues for the identity of courage and knowledge, and at 350C6351B2 Protagoras objects to Socrates' argument. Between 1961 and 1985, a few valuable contributions in English were made to the interpretation of these passages. ${ }^{1}$ None, however, is entirely satisfactory. And in the last twenty years, among some cursory treatments in studies not particularly focused on these passages, ${ }^{2}$ no notable progress has been made.

The objective of this paper is to present a more satisfactory interpretation of Socrates' argument and Protagoras' objection, in particular by engaging with a set of problems with which previous commentators have wrestled. Above all, I will be concerned with Taylor's examination of these problems since his contribution remains the most thorough and well known in English. ${ }^{3}$

The upshot of my discussion is that both Socrates' argument and Protagoras' response are more cogent than has been recognized. Indeed, Protagoras suggests a good reason to believe that Socrates' argument fails to identify courage and knowledge. This also explains Socrates' development of a second argument for the identity of courage and knowledge (351B-360E).

In clarifying the hermeneutic problems in Socrates' first argument and Protagoras' objection, it will be convenient to begin with a basic outline of Socrates' argument. The actual complexities of the argument will be clarified in the course of the ensuing discussion.

(1) Courageous men are confident.

(2) Courage, qua part of excellence, is fine.

(3) Knowledgeable men are confident.

(4) Some without knowledge are confident.

(5) Ignorant confidence is base.

(6) Therefore, courage is knowledge.

According to this description, Socrates attempts to identify courage and knowledge on the grounds that both are fine confidence. Collectively, commentators have drawn attention to three serious problems with the argument. I will introduce and resolve each in turn.

\section{PROBLEM 1: THE ARTICLE AT 350B7}

Socrates begins his argument by eliciting Protagoras' assent to the following question:

'Do you speak of the courageous as confident?'

Protagoras commits to (1), the courageous are confident. But after it is agreed that (5), the ignorant confident are base, Socrates poses the following questions:

pôs oun, ephên egô, legeis tous anreious? ouxi tous tharraleous einai? ${ }^{5}$

A natural translation is:

'What, then,' I said, 'do you say of the courageous? Do you not say that they are the confident?'

And a natural interpretation of this is that Socrates is suggesting that courage and confidence are identical.

At the same time, Protagoras responds to Socrates' question: 'I still do now'; 6 and this suggests that he interprets the proposition as identical to (1). And yet again, in response to Socrates' argument, Protagoras subsequently says:

\footnotetext{
1 Michael O' Brien, 'The "Fallacy" in Protagoras 349D-350C", Transactions of the American Philological Association 92 (1961), 408-17; Daniel T. Devereux, 'Protagoras on Courage and Knowledge: Protagoras 351A-B', Apeiron 9 (1975), 37-9; C. C. W. Taylor, Plato Protagoras (Oxford, 1976; reprinted with revisions in 1991), 150-61; Rosalyn Weiss, 'Courage, Confidence, and Wisdom in the Protagoras', Ancient Philosophy 5 (1985), 11-24.

2 For example, Daniel C. Russell, 'Protagoras and Socrates on Courage and Pleasure: Protagoras 349D ad finem', Ancient Philosophy 20 (2001), 311-38.

3 Taylor (n.1).

4 poteron tous andreious tharraleous legeis ê allo ti? (Prt. 349E2)

5 Prt. 350B6-7.
} 
(P1) 'When you asked me whether the courageous are confident, I agreed; but you did not ask me whether in addition the confident are courageous. If you had asked me that, I would have said, not all. ${ }^{7}$ identical.

So here Protagoras himself seems to interpret Socrates as maintaining that courage and confidence are

Problem 1, then, is that Socrates' argument clearly depends upon courage being a type of confidence. Therefore, if Socrates were suggesting at 350B7 that courage and confidence are identical, he would be, as Vlastos writes, 'an utter fool'. ${ }^{8}$ I see no good grounds for maintaining that Plato is here characterizing Socrates as an utter fool. ${ }^{9}$

Excluding this possibility, the following alternative explanations of the article at $350 \mathrm{~B} 7$ should be considered. Some editors have excised the article. ${ }^{10}$ Some editors have changed the article to a pronoun, for instance, toutous. ${ }^{11}, 12$ Finally, some commentators have argued that Socrates is using the article unusually.

This last approach, the unconventional use of the article, has been endorsed by many scholars: prior to 1976, Stalbaum and Kroschel, Nestle, Grube, Bluck, and Vlastos; ${ }^{13}$ since 1976, Taylor and Weiss. However, O' Brien's paper of 1961 is the most thorough consideration of this problem, and drawing on special studies as well as discussions in the standard grammars, O' Brien concludes that the article is used with the predicate only in asserting or denying identity. ${ }^{14}$

Taylor is, then, the first scholar to reject O' Brien's conclusion. ${ }^{15}$ To make his case, Taylor refers to three instances among the early Platonic dialogues where Socrates uses the expression 'the $F$ are the $G$ ' to predicate $G$ of a set of $F$ entities: Laches 195E1, Protagoras 342B4-5, and Gorgias 491E2.

At Laches 195E1, Laches says that according to Nicias' view of courage, the seers are tous andreious (the courageous). But this passage does not support Taylor's position. Laches here interprets Nicias to mean precisely that the only individuals who are courageous are those who have the knowledge of seers.

At Protagoras 342B4-5, Socrates says that Cretans and Spartans conceal their knowledge hôsper hôu Prôtagoras elegee tous sophistas. Taylor suggests that this could be read as 'just as those whom Protagoras was saying are sophists'. ${ }^{16}$ This is wrong. Lombardo and Bell, Manuwald, and Croiset all treat the phrase tous sophistas as a subject. ${ }^{17}$ Its case is to be explained by 'inverse attraction', that is, attraction into the case of the relative pronoun, viz.: 'just as the sophists [do], whom Protagoras was discussing'. ${ }^{18}$ Compare the following other instances

\footnotetext{
6 kai nun g' (Prt. 350B7)

7 Prt. 350C7-D1.

8 Gregory Vlastos, ed., Plato Protagoras (Indianapolis, 1956), xxxii, cited from Weiss (1985), 14.

${ }^{9}$ Russell does not discuss this point. I presume he takes it as settled in favor of Weiss and Taylor.

10 M. Schanz, Platonis opera quae feruntur omnia, Bd. 7 (Leipzig, 1873; reprinted with revisions in 1880); H. Sauppe, Platons ausgewählte Dialoge, Bd. 2 (Berlin, 1884). See O'Brien (n.1), n. 10 for an account of his predecessors' responses to the problem.

11 Sauppe (n.10) suggests this as well.

12 Another possibility is to resist treating tous tharraleous as a phrase and, instead, take tous as the subject of the infinitive, anaphoric for tous andreious of the last sentence, and tharraleous as a predicate adjective on its own. As far as I know, this suggestion has not been entertained. There are two problems with it. One is that although the article can be used as a personal pronoun, it is so used chiefly after kaiv; see Smyth $§ 1113$. The other is that even if we were to allow the possibility of such usage without kai, it would be grossly misleading and clumsy of Socrates (and so Plato) to deploy it here of all places.

13 See O’ Brien (1961), 411 and n. 10.

14 L. Dornseiffen, De articulo apud Graecos euisque usu in praedicato (Amsterdam, 1856); A. Procksch, 'Über den gebrauch des artikels, insbesondere beim prädikat', Philologus 40 (1881), 156-210. O' Brien (n.1) also refers to Smyth, Gildersleeve and Miller, and Kühner and Gerth. Procksch concludes: that: 'Die bedeutung des artikels beim prädikat ist immer die der identität oder (neigert, oder wenn das prädikat thateron oder tounantion ist) nicht-identität, mag dieselbe nun eine begriffliche oder thatsächliche sein.' (47) cited by O' Brien (n.1), 411.

15 Weiss (n.1), 16 and n.15 follows Taylor with little compelling additional argumentation.

16 Taylor (n.1), 159.

17 Lombardo and Bell, trans., in J. Cooper, Plato Complete Works (Indianapolis, 1997), 773; A. Croiset, Protagoras (Paris, 1997), 97: 'comme les sophistes dont parlait Protagoras'; Bernd Manuwald, Platon Protagoras (Göttingen, 1999), 332: 'wie die Sophisten von denen Protagoras sprach'. Manuwald comments: 'Zur Hineinnahme des Bezugswortes in den Relativsatz vgl. K. G. II 417.'

18 See Smyth $\S \S 2533-4$ who also cites Cra. 45C, Chrm. 175C, and Plt. 308B.
} 
in Plato: oute autoi oute hous phamen hêmin paideuteon einai tous phulakas (R. 402C1-2); ${ }^{19}$ has de su legeis tas skepseis (Cri. 48C2); ${ }^{20}$ en hois su eleges tois logois (Prt. 359D3). ${ }^{21}$

At Gorgias 491E2, on the basis of Socrates' conception of sound-mindedness as control over desires and pleasures, Callicles says: 'You are saying that the sound-minded are tous êlithious (the stupid)' ${ }^{22}$ Taylor suggests that Callicles 'may mean no more than that all [people who control their desires and pleasures] are [stupid]'. ${ }^{23} \mathrm{O}$ ' Brien assumes without argument that Callicles means that the sets of those who control their desires and pleasures and the stupid are identical. ${ }^{24}$ The problem is that, normally, the logico-semantic interpretation of the sentence would favour O' Brien's interpretation, yet Callicles surely does not intend to commit to the view that all who are stupid control their desires and pleasures.

I suggest that the following linguistic peculiarity occurs at Gorgias 491E2. The normal logico-semantic interpretation of noun-phrases composed of the article and adjective is that the article functions as a universal quantifier that ranges over the domain of entities characterized according to the adjective. For example, 'the poor' ranges over all those who are poor. In most cases, the universe of discourse in terms of which the domain is defined is the actual world or all possible worlds. Still, pragmatic conditions often affect, by restricting, the universe to, say, all pertinent entities within the speaker's immediate environment. For example, a teacher may request that all the third-graders form a line, by which he means, and his students understand, all the third-graders in his classroom.

In Callicles' statement, a different kind of restriction occurs. The domain over which the article in the predicate 'the stupid' ranges is the actual world or, perhaps, all possible worlds. But since the subject 'the soundminded' has been interpreted as 'those who control their desires and pleasures', the domain over which the quantifier ranges is not merely characterized by the property of being stupid. Rather, it is characterized by the property of being stupid insofar as one controls one's desires and pleasures (and this, versus one who does not control one's desires and pleasures). In other words, Callicles' statement amounts to 'the sound-minded are the stupid (ones from among the set of those who control and those who do not control their desires and pleasures insofar as they control or do not control their desires and pleasures)'.

In sum, at Gorgias 491E2 Callicles should be interpreted as claiming that the sound-minded and the stupid are identical, insofar as the set of the stupid he has in mind is restricted as suggested. Accordingly, insofar as the use of the article with a predicate adjective in Protagoras is concerned, the Gorgias example does not support Taylor's position. So, in short, none of the examples Taylor cites supports his position.

In view of the discussion of Gorgias 491E2, the question may, incidentally, be raised whether the phrase tous tharraleous at Protagoras 350B7 is interpretable in some similar, relatively anomalous way. I don't see that it is. Consequently, the weight of the evidence - that Socrates is not an utter fool and that there is no indication elsewhere in Plato of the use of the article with a predicate other than to state or deny identity - suggests that the text must here be corrupt and that tous should be excised or altered. I leave open the question which solution is preferable, for in either case the meaning of Socrates' question is now clarified as: Do you speak of the courageous as confident?

Granted, then, that Socrates does not commit a gross logical error in his argument, there remains Protagoras' response (P1), not all confidence is courageous, following the argument. ${ }^{25}$ Weiss suggests that this is a non sequitur and that there is nothing odd about Protagoras' misinterpretation of Socrates' argument. ${ }^{26}$ Similarly, Taylor tentatively accepts that 'it is well within the bounds of reasonable dramatic possibility that Plato should represent Protagoras as giving an incorrect diagnosis of the fallacy, in order to expose his limitations as a critic of arguments'. 27 Generally speaking, I agree that Plato might characterize Protagoras or some other Socratic interlocutor as an incompetent dialectician. But in this particular instance, for a couple reasons, I strongly doubt it. First, it would make now Protagoras an utter fool; it is Protagoras himself who correctly infers that the ignorant

19 Cited by L. Reinhard, 'De Anakoluthe bei Platon', Philologische Untersuchungen 25 (1920), 21-46, at 32.

20 Cited by J. Adam, Platonis Protagoras (Cambridge, 1893), ad loc.

21 Cited by Manuwald (n.17), 332, to whom I am indebted for the preceding two citations.

22 A more natural translation is: 'By the sound-minded you mean the stupid', although this is misleading insofar as Callicles is not speaking of the meaning of phrases.

23 Taylor (n.1), 159

24 O' Brien (n.1), n. 8.

25 Protagoras' immediate response at 350B7 now emerges as consistent with his commitment to (1).

26 Weiss (n.1), 16-7.

27 Taylor (n.1), 160. 
confident are not courageous since, then, courage would be base. Accordingly, Protagoras clearly recognizes that Socrates' argument depends on the courageous being a subset of the confident. Furthermore, as I will discuss in section V, Protagoras proceeds to offer a cogent criticism of Socrates' argument.

Assuming this, it remains a question how (P1) is to be interpreted. I suggest that (P1) is slightly elliptical. When he admits that the courageous are confident, but that not all confident men are courageous, Protagoras means that not all fine confident men are courageous. As I will show in section V, this interpretation makes good sense of Protagoras' ensuing objection to Socrates' argument. Moreover, the suggestion that Protagoras' statement is elliptical is consistent with what I take to be the elliptical character of his immediately following account of Socrates' argument:

'Then you show that people when they have knowledge are more confident than when they lack it and also than others who are ignorant, and on that basis you conclude that courage and knowledge are the same thing. ${ }^{28}$

Weiss accuses Protagoras of misinterpreting Socrates' argument specifically insofar as Protagoras says nothing about the premise that courage, qua part of excellence, is a fine thing. It is surely preferable to treat Protagoras' account as elliptical and specifically as omitting, but not ignoring the premise that courage is fine since, again, it is Protagoras who infers that the ignorant confident cannot be courageous since that would make courage a base thing. ${ }^{29}$ In short, Protagoras, clearly, is alive to the operation of (2), courage qua part of excellence is fine, in the argument; he simply expresses himself in (P1) and in the quotation above in a condensed and so elliptical fashion.

\section{PROBLEM 2: THE CONFIDENCE OF THE KNOWLEDGEABLE AND THE IGNORANT}

Premise (3), knowledgeable men are confident, simplifies a set of claims. Given that courageous men are confident and that courage is fine, it follows, although this is not made explicit, that courage is a form of fine confidence. Assuming - what is subsequently confirmed - that some forms of confidence are base, Socrates now engages the question of what makes some confidence fine. His assumption, of course, is knowledge. Thus, he elicits Protagoras' assent to the claim that those who dive into wells have confidence because they possess relevant knowledge. ${ }^{30}$ Socrates then elicits Protagoras' assent to the claim that skilled horsemen and peltasts, in contrast to unskilled men, are confident in going to war. ${ }^{31}$ This provokes Protagoras' following statement:

(P2) 'And in every other case, if this is the answer you are looking for, those who have knowledge are more confident than those who lack it.' 32

Taylor has suggested that (P2) is false and that it does not support Socrates' conclusion. It is false because in some instances, unskilled men are more confident than skilled men. Moreover, if this is granted and (P2) is then reduced to:

(P2') All knowledgeable men are sometimes confident, then (P2') will only support the weaker conclusion that all knowledgeable men are sometimes courageous. ${ }^{33}$

Taylor's worry might simply be dismissed on the grounds that (P2) is Protagoras' statement, not Socrates'. Yet just before Socrates draws the final conclusion to his argument, he says:

(3') '[With respect to divers, horsemen, and peltasts,] the most knowledgeable are also the most confident.' 34

So (P2) does appear to conform to a premise to which Socrates himself is committed.

And yet again, following (P2), Socrates elicits Protagoras' assent to (4), some men without knowledge are confident. And by introducing (4) Socrates seems to be indicating that in stating (P2), Protagoras has drawn too general an inference. If Socrates were introducing (4) for that reason, he would, apparently, be contradicting himself at (3').

28 Prt. 350D2-5.

29 In section V, I further clarify the elliptical nature of Protagoras' statement.

30 Prt.350A1-3.

31 Prt. 350A3-5.

32 Prt. 350A6-7.

33 Taylor (n.1), 152-3.

34 Prt. 350C2-3. 
These difficulties can be resolved as follows. First, we should not take (4) to contradict (P2). Rather, we should take Protagoras, in stating (P2), to mean that the knowledgeable qua knowledgeable are more confident than the ignorant qua ignorant. In other words, Protagoras is admitting that knowledge, as opposed to ignorance, is a source of confidence. ${ }^{35}(4)$, then, suggests that since some ignorant men are confident, there must be another source of confidence besides knowledge - although it also suggests that this source of confidence is not fine. Protagoras indicates the alternative source when he says: 'these men are crazy'; 36 and Socrates subsequently accepts this suggestion himself. ${ }^{37}$

It is immediately after accepting that the ignorant confident are not courageous but crazy that Socrates suggests (3'). Note that his suggestion of (3') begins with kai ekei (and with respect to the former cases). This indicates that Socrates is now referring back to the divers, horsemen, and peltasts. Accordingly, in claiming that in these sorts of cases, the most knowledgeable are the most confident, Socrates should only be taken to mean that the most knowledgeable qua knowledgeable, and in contrast to the ignorant, are the most confident. ${ }^{38}$ In short, then, in suggesting (3') Socrates is recapitulating Protagoras' point (P2). ${ }^{39}$

\section{PROBLEM 3: KNOWLEDGE, COURAGE, AND CONFIDENCE}

Socrates draws his final conclusion thus:

kai ekei au hoi sofôtatoi houtoi kai tharraleôtatoi eisin, tharraleôtatoi de ontes andreiotatoi? kai kata touton ton logon hê sophia an andreia eiê, 40

This has been translated as:

'And in the former cases [namely, the skilled divers, horsemen, and peltasts,] (i) the most knowledgeable are the most confident, and (ii) being most confident they are the most courageous? (iii) So on this reasoning, knowledge would be (eiê) courage?'

Taylor suggests that Socrates' inference of (ii) is invalid. ${ }^{41}$ In other words, it does not follow from the previous claims in the argument in conjunction with the claim here that the most knowledgeable are most confident that the most confident are the most courageous. I agree that the inference is invalid. However, I suggest that the function of the invalidity of (ii) has been misunderstood as a result of the text's punctuation. Rather than taking (i) and (ii) as part of the same sentence, as all editors do, ${ }^{42}$ I propose to place the question mark after (i) and to take (ii) and (iii) as part of the same sentence thus:

kai ekei au hoi sofôtatoi houtoi kai tharraleôtatoi eisin? tharraleôtatoi de ontes andreiotatoi kai kata touton ton logon hê sophia an andreia eiê.

As a result, (ii), with (iii), will now be read as in the optative rather than the indicative mood, viz.:

'In contrast, then, in the former cases our most knowledgeable men [namely, the skilled divers, horsemen, and peltasts] are indeed the most confident? Then, being the most confident, they would be the most courageous, and, on this reasoning [that is, that the most confident are the most courageous], knowledge would be courage.'

On this interpretation, (ii) and (iii) are taken as Socrates' inferences from the argument as a whole, with (iii) itself following unproblematically from (ii).

\footnotetext{
35 This too is how Protagoras' additional claim should be understood: "and men are more confident after they have learned than before." (Prt. 350A7-B1)

36 Prt. 350B5-6.

37 Prt. 350C1-2. I should note that I take it that Socrates' acceptance of this view is merely a dialectical expedient- this, in view of his subsequent analysis of the weakness of being overcome by pleasure as ignorance.

38 The superlative here may be interpreted as an attempt also to convey the idea that confidence based on knowledge increases correlatively with increase in knowledge, which also corresponds with Protagoras' point at 350A7-B1.

${ }^{39}$ Related to this solution to problem 2 is the following. As we have seen, in agreeing to (5), ignorant confidence is base, Protagoras also says that the ignorant confident are not courageous since, then, courage would be base. Taylor suggests that this inference is invalid, for the ignorant confident may possess courage otherwise. Given that the ignorant confident are, as Protagoras suggests, crazy, Taylor writes: 'The argument would require the additional premise that no one who is [crazy] possesses any of the virtues.' (n.1) 154-5 Taylor's objection can be answered simply. The intention of the claim- surely- is that the ignorant confident are base in respect of their ignorant confidence.

40 Prt. 350C2-5.

41 Taylor (n.1), 154-5.

42 I have not found an edition with an alternative.
} 
The point of the emendation in punctuation, then, is not to demonstrate that (ii) or (iii) are validly inferred from the preceding argument; they are not. It is simply to clarify that (ii) and (iii) constitute Socrates' conclusion from the preceding argument.

\section{PROTAGORAS' OBJECTION TO SOCRATES' ARGUMENT: $350 \mathrm{C}-351 \mathrm{~B}^{43}$}

The problem with the inference of (ii) from the preceding argument is as follows. Given that courage is fine, courage is a type of confidence, and confidence engendered by knowledge is fine, still, there may be two distinct sources of fine confidence: knowledge and courage. ${ }^{44}$ This, I suggest, is precisely Protagoras' objection.

Protagoras initially makes his point as follows:

'you show that those who have knowledge are more confident than those who lack knowledge and thereby you take courage and knowledge to be the same. But if you go about it that way, you might maintain that strength is the same as knowledge. 45

This statement is rather elliptical. The argument form is reductio: if one argues as Socrates does, one can conclude that strength is knowledge; but this, so Protagoras thinks, is absurd; therefore, Socrates' argument is invalid.

We can clarify the ellipses in Protagoras' statement as follows:

Socrates has tried to show that since knowledge $<$ versus ignorance $>$ is a form of $<$ fine $>$ confidence $<$ and courage is a form of fine confidence $>$, it follows that knowledge and courage are identical.

Protagoras now proceeds to clarify why this is false. He proposes that strength is a type of power and that the source of strength is the conjunction of nature (phusis) and good nurture of the body. For other kinds of power, there are three other sources: knowledge, craziness, and rage. Analogously, Protagoras grants that courage is a type of confidence; however, he claims that the source of courage is the conjunction of nature and good nurture of the soul, whereas for other kinds of confidence, there are three other sources: skill (technê), craziness, and rage. ${ }^{46}$

Let us be clear what Protagoras is suggesting in this analogy. By 'strength' he means the sort of brute physical power that some people can develop through training their bodies because their bodies are naturally suited to such cultivation, for example, the strength of a professional boxer or weightlifter. Contrast this with the use of ingenuity to move a large object; a strong man lifts the object, while Archimedes devises a fulcrum. Furthermore, in episodes of craziness and rage, the body is temporarily able to achieve more than usual, but such cases do not exemplify strength. Analogously, Protagoras understands courage to be a kind of psychological toughness cultivated through training of the soul of an individual whose soul is naturally constituted to respond well to such training. A professional soldier may exemplify this. Moreover, the confidence of the courageous person differs from confidence derived from the acquisition of knowledge or through some delusion or passion. For example, a doctor may have confidence in performing a surgery, and a parent may confidently lash out in response to some perceived or real attack on his or her child.

Above we suggested that Protagoras' initial objection, (P1), not all confidence is courageous, is to be taken as elliptical for not all fine confidence is courage. We suggested that this interpretation would be consistent with our interpretation of Protagoras' ensuing objection. It is clear now that Protagoras can consistently maintain that knowledge is a form of fine confidence, but not identical to courage, since although courage is also a form of fine confidence, courage is engendered by natural constitution and good nurture of the soul, and not by knowledge.

\footnotetext{
43 My interpretation of Protagoras' objection, particularly regarding Protagoras' conception of the relation between courage and knowledge, is compatible with Devereux (n.1). However, Devereux does not resolve the apparent contradiction between (P1) and (1), and he does not explain (P2). It is noteworthy that Weiss, who suggests that Protagoras' objection is misguided, does not engage with Devereux's discussion.

44 Taylor (n.1), 155-6 protests that Socrates has only argued that all the courageous are knowledgeable, not that all and only the courageous are knowledgeable. Similarly, Weiss (n.1), 15 suggests that the problem of the invalidity of (ii) is that courage may be a type of knowledge.

45 Prt. 350D3-6.

46 I am grateful to an anonymous referee for rightly insisting that Protagoras does not conceive of nature and training as alternative routes to strength or courage, but a "single, two-stage route". This is consistent with Protagoras' claims in the Great Speech. See Taylor (n.1), ad loc. and on 323D7.
} 
Accordingly, we can also see how Protagoras thinks Socrates' form of argument, when applied to the relation between knowledge and strength, will yield the conclusion, absurd according to Protagoras, that strength is knowledge. On the grounds that strength is a form of power and fine and knowledge is a form of power and fine, Socrates would have us believe that strength and knowledge are identical. But just as courage is engendered by natural constitution and good nurture of the soul, not by knowledge, so strength is engendered by natural constitution and good nurture of the body, not by knowledge.

\section{CONCLUSION}

I conclude this discussion of Socrates' argument for the identity of courage and knowledge at Protagoras 349E1-350C5 and Protagoras' objection at 350C6-351B2 with three remarks that may serve for future research into these passages.

First, Protagoras' objection has at least two potential difficulties. One is that Protagoras must be able to explain what makes the particular toughness of the soul acquired by nature a fine thing. The other is that Protagoras must be able to distinguish the skill that is the source of one form of fine confidence from the good nurture that is the form of another. One may be inclined to collapse the two into knowledge, so Protagoras needs to show that the good nurture of the soul that yields courage is distinct from learning a skill such as well diving.

Second, it is a question to what extent Protagoras' conception of courage and its modes of acquisition is compatible with the content of his Great Speech at 320C8-328C2. The compatibility of the two would certainly lend further support to the foregoing arguments. The incompatibility of the two might weaken the foregoing arguments, or at least require the view that Protagoras does not maintain a consistent conception of the cultivation of excellence in these sections of the dialogue.

Third, one cannot fail to be impressed by Plato's cleverness, given the fact that in the ensuing examination of the weakness of being overcome by pleasure, Socrates crucially employs, with Protagoras' admission, the view that knowledge is strength, precisely the claim that Protagoras treats as absurd in his objection to Socrates' argument. Socrates' second argument is surely linked to Protagoras' objection to his first argument. But, more precisely, one expects that Socrates' second argument will answer Protagoras' objection. Given my account of Protagoras' objection, this means that Socrates will show either that there cannot be some other form of fine confidence which comes by knowledge or that courage cannot come by nature or good nurture of the soul or, finally - in view of remark one - that in the case of courage, knowledge and good nurture of the soul cannot be distinguished. 
